\title{
Corrosion study of the passive film of amorphous Fe-Cr-Ni-(Si, P, B) alloys ${ }^{(\bullet)}$
}

\author{
M.F. López ${ }^{(*)}$, M.L. Escudero ${ }^{(*)}$, E. Vida $^{(*)}$, A.R. Pierna ${ }^{(* *)}$, F.F. Marzo ${ }^{(* *)}$ \\ and A. Lorenzo $(* *)$
}

\begin{abstract}
Amorphous $\mathrm{Fe}_{62} \mathrm{Cr}_{10} \mathrm{Ni}_{8} \mathrm{X}_{20}(\mathrm{X}=\mathrm{P}, \mathrm{B}, \mathrm{Si})$ alloys in $0.01 \mathrm{M} \mathrm{HCl}$ solution have been investigated by means of standard electrochemical measurements in order to evaluate their corrosion resistance. The study reveals that the best corrosion behaviour is given by the Si containing amorphous alloy. X-ray photoelectron spectroscopy (XPS) and Auger electron spectroscopy (AES) have been employed to study the composition of the passive layers, formed on the surface of the different amorphous alloys. The results on $\mathrm{Fe}_{62} \mathrm{Cr}_{10} \mathrm{Ni}_{8} \mathrm{Si}_{20}$ show that a protective passive film, mainly consisting of oxidized chromium, greatly enhances its corrosion resistance.
\end{abstract}

Keywords: Amorphous alloys. Corrosion. EIS. Photoemission. Passive layer.

\section{Estudio del comportamiento frente a la corrosión de las capas pasivas formadas sobre las aleaciones amorfas $\mathrm{Fe}-\mathrm{Cr}-\mathrm{Ni}-(\mathrm{Si}, \mathrm{P}, \mathrm{B})$}

\begin{abstract}
Resumen La resistencia a la corrosión de las aleaciones amorfas $\mathrm{Fe}_{62} \mathrm{Cr}_{10} \mathrm{Ni}_{8} \mathrm{X}_{20}(\mathrm{X}=\mathrm{P}, \mathrm{B}, \mathrm{Si}$ ) inmersas en $\mathrm{HCl} 0,01 \mathrm{M}$ se evaluó usando técnicas electroquímicas. Las técnicas de espectroscopía de fotoemisión de rayos X y espectroscopía Auger se emplearon para estudiar la composición de las capas pasivas, formadas en aire sobre la superficie de las aleaciones amorfas. Del estudio realizado se concluye que el mejor comportamiento frente a la corrosión viene dado por la aleación amorfa que contiene como metaloide Si. Esto es debido a que la capa pasiva de dicha aleación está formada principalmente de óxido de cromo, lo cual confiere una alta resistencia a la corrosión.
\end{abstract}

Palabras clave: Aleaciones amorfas. Corrosión. EIS. Fotoemisión. Capa pasiva.

\section{INTRODUCTION}

Rapidly quenched amorphous metal-metalloid alloys containing a certain amount of chromium are materials that exhibit extremely high corrosion resistance (1-6). They do not suffer pitting corrosion in acidic chloride solutions even under anodic polarization and also show a significantly high resistance to crevice corrosion (7-9). This corrosion behaviour depends on the presence of a protective passive film and, therefore, on its composition.

$(\bullet)$ Trabajo recibido el día 30 de mayo de 1996.

(*) Centro Nacional de Investigaciones Metalúrgicas (CSIC). Avda. de Gregorio del Amo, 8. 28040-Madrid (Spain).

(**) Dpto. de Ingeniería Química y del Medio Ambiente. Univ. del País Vasco. E.U.I.T.I. de San Sebastián. Avda. de Felipe IV, 1-B. Apdo. 1.379 (Spain).
Passive films on amorphous iron-chromium base alloys are constituted mainly of hydrated chromium oxihydroxide (10). The corrosion resistance and protection of amorphous alloys improve highly with the content of this chromium oxihydroxide film (11). The high reactivity of amorphous alloys is the responsible of the chromium enrichment in the passive film, and their chemically homogeneous nature provides high passivating ability and corrosion resistance. For this reason, alloys which form stable passive films, most notably $\mathrm{Cr}$ containing alloys, have been studied quite extensively (4, 8 and 12-14).

In the present work, we have performed electrochemical measurements along with X-ray photoelectron spectroscopy (XPS), and Auger electron spectroscopy (AES) of amorphous $\mathrm{Fe}_{62} \mathrm{Cr}_{10} \mathrm{Ni}_{8} \mathrm{X}_{20}$ (X=P, B, Si) alloys, and investigated the role of the passive film composition on the corrosion behaviour of the samples. 


\section{EXPERIMENTAL}

Alloy ingots were prepared by arc melting in a water cooled copper crucible under $\mathrm{He}$ atmosphere. From these ingots, amorphous alloy ribbons of about $5 \mathrm{~mm}$ and $20-30 \mu \mathrm{m}$ thickness were prepared by the planar flow casting method. Ribbon compositions were checked by electron probe microanalysis. The amorphous structure of the samples was confirmed by X-ray diffraction. Prior to the electrochemical experiments, the amorphous alloy ribbons were degreased in acetone and rinsed with distilled water.

Electrochemical measurements were made at room temperature using as electrolyte $0.01 \mathrm{M} \mathrm{HCl}$. An area of $2 \mathrm{~cm}^{2}$ of the amorphous alloy ribbons, acting as working electrodes, was exposed in this solution. A saturated calomel reference electrode and a stainless steel wire as counter electrode were used for the evaluation of the corrosion behaviour.

XPS and Auger spectra were recorded under ultra-high vacuum (UHV) conditions with a VGCLAM hemispherical electron energy analyzer equipped with a special lens to probe small areas on the sample $\left(<1 \mathrm{~mm}^{2}\right)$. Additionally, both an electron gun with a spot size of $50 \mu \mathrm{m}$ and $3 \mathrm{keV}$ acceleration energy as excitation source for the Auger spectra and a Mg X-ray source was used for the XPS spectra were used. The base pressure in the UHV-chamber during measurements was better than $10^{-9}$ mbar. Samples were cleaned by sputtering with an ion gun operating with $2 \mu \mathrm{A}$ sample current and an ion energy of $3 \mathrm{keV}$.

\section{RESULTS AND DISCUSSION}

Figure 1 shows the values of the corrosion intensity, $i_{\text {corr }}$ versus testing time for three different amorphous alloys, $\mathrm{Fe}_{62} \mathrm{Cr}_{10} \mathrm{Ni}_{8} \mathrm{X}_{20}(\mathrm{X}=\mathrm{P}, \mathrm{B}, \mathrm{Si})$. These data are obtained from the measurements of polarization resistance, $R_{\mathrm{p}}$. For this purpose, potential steps of 10 and $50 \mathrm{mV}$ were applied and the intensity $\Delta I$ was registered. Under a $10 \mathrm{mV}$ step, the response in intensity for most of the samples diminished very fast to zero before any stationary stage was achieved. Furthermore, in some cases the obtained values approached the detection limit of the equipment, therefore it was necessary to apply a step of $50 \mathrm{mV}$. The value of the polarization resistance $R_{\mathrm{p}}$ is deduced from the quotient $R_{\mathrm{p}}=\Delta E / \Delta I$, where $\Delta E$ is the step of the potential applied at the corrosion potential and $\Delta I$ is the resulting current for a testing time of $60 \mathrm{~s}$. After determining the polarization resistance, the corrosion intensities, $i_{\text {corr }}$, could be immediately determined by applying the well-known Stern-

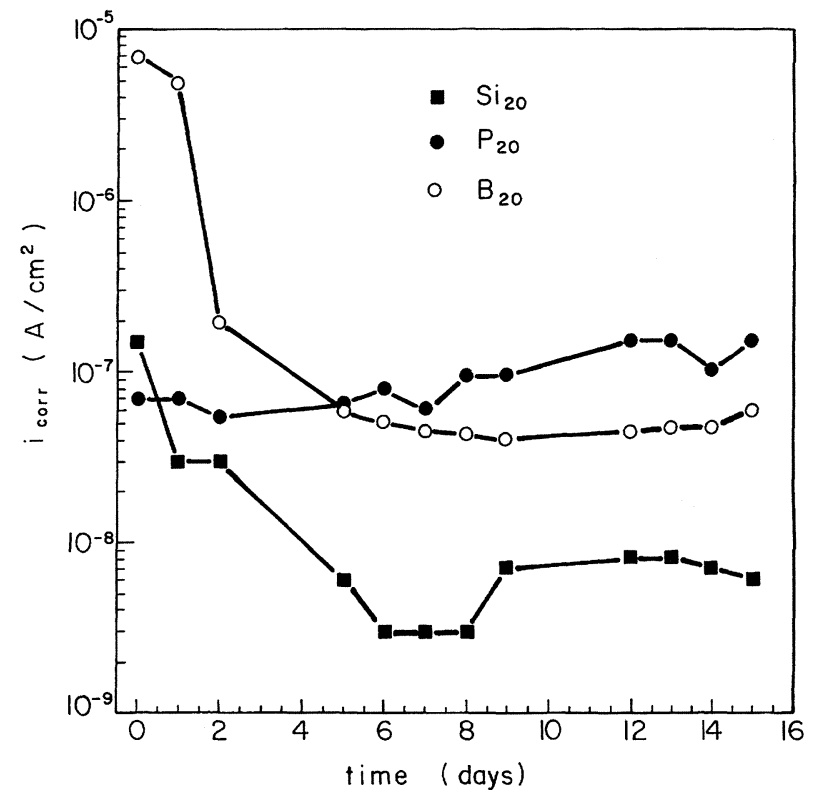

FIG. 1.- Corrosion current density, $i_{\text {corr }}\left(\mathrm{A} / \mathrm{cm}^{2}\right)$ as a function of time for the three studied alloys: $\mathrm{Fe}_{62} \mathrm{Cr}_{10} \mathrm{Ni}_{8} \mathrm{X}_{20}(\mathrm{X}=\mathrm{P}, \mathrm{B}, \mathrm{Si})$.

FIG. 1.- Densidad de corriente de corrosión, $i_{\text {corr }}$ $\left(A / \mathrm{cm}^{2}\right)$ en función del tiempo para las tres aleaciones estudiadas: $\mathrm{Fe}_{62} \mathrm{Cr}_{10} \mathrm{Ni}_{8} \mathrm{X}_{20}(\mathrm{X}=\mathrm{P}, \mathrm{B}, \mathrm{Si})$.

Geary equation $\left(i_{\text {corr }}=B / R_{\mathrm{p}}\right)$, where $B$ is a constant containing Tafel slope information. The value of $B$ for each amorphous alloy was previously deduced from the anodic and cathodic slopes of the polarization curves.

From the data represented in figure 1, we can clearly see that the lower corrosion intensity corresponds to $\mathrm{Fe}_{62} \mathrm{Cr}_{10} \mathrm{Ni}_{8} \mathrm{Si}_{20}$ amorphous alloy, presenting $i_{\text {corr }}$ values at least one order of magnitude lower than the other alloys. Therefore, in a first step, with the polarization resistance method we observe that the amorphous alloy containing $\mathrm{Si}$ gives the best corrosion behaviour.

The corrosion resistance can be also evaluated by means of the altern current impedance method, also known as electrochemical impedance spectroscopy (EIS). For these measurements a sinusoidal potential variation with $10 \mathrm{mV}$ amplitude was applied within a frequency range from $0.01 \mathrm{~Hz}$ to $64,000 \mathrm{~Hz}$ and the resulting current was collected and measured. Figure 2 represents the Nyquist plot obtained for the different amorphous alloys after 15 days of immersion in $0.01 \mathrm{M} \mathrm{HCl}$. In this diagram the real and imaginary parts of the impedance are plotted as a function of the frequency. The semicircle of the Nyquist diagram can be extrapolated and it is possible to calculate the transfer resistance, $R_{\mathrm{t}}$, that corresponds to the diameter of the Nyquist plot semicircle. From figure 2 we can observe that the best corrosion 


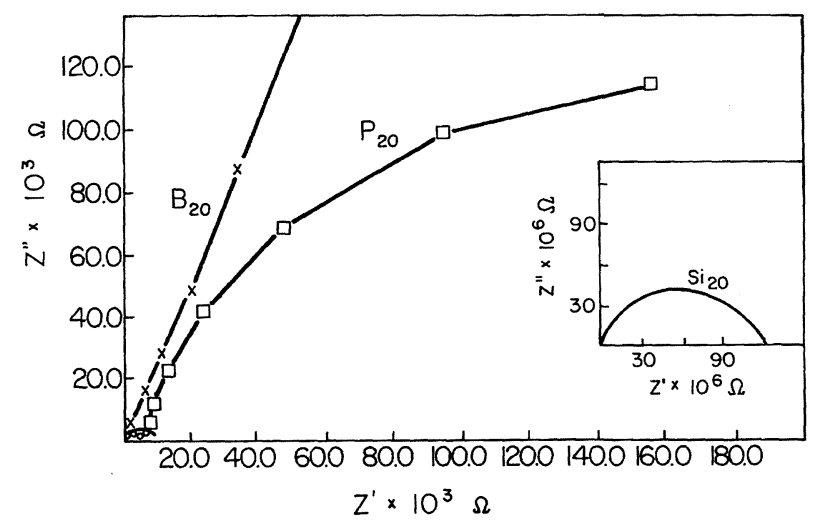

FIG. 2.- Nyquist plot of $\mathrm{Fe}_{62} \mathrm{Cr}_{10} \mathrm{Ni}_{8} \mathrm{X}_{20}(\mathrm{X}=\mathrm{P}, \mathrm{B}$, $\mathrm{Si}$ ) amorphous alloys after 15 days of immersion in $0.01 \mathrm{M} \mathrm{HCl}$.

FIG. 2.- Diagrama de Nyquist de las aleaciones amorfas $\mathrm{Fe}_{62} \mathrm{Cr}_{10} \mathrm{Ni}_{8} \mathrm{X}_{20}(\mathrm{X}=\mathrm{P}, \mathrm{B}, \mathrm{Si})$ después de 15 días de immersión en $\mathrm{HCl}$ 0,01M.

behaviour, in agreement with the polarization resistance method, is given by the $\mathrm{Fe}_{62} \mathrm{Cr}_{10} \mathrm{Ni}_{8} \mathrm{Si}_{20}$ amorphous alloy, shown in the figure inset. $\mathrm{Fe}_{62} \mathrm{Cr}_{10} \mathrm{Ni}_{8} \mathrm{~B}_{20}$ amorphous alloy shows a Nyquist plot semicircle that is not complete. In these cases $R_{\mathrm{t}}$ values can approximately be obtained from the lower frequency impedance data. The Nyquist plot for $\mathrm{Fe}_{62} \mathrm{Cr}_{10} \mathrm{Ni}_{8} \mathrm{P}_{20}$ amorphous alloy exhibits two different arcs, a small semicircle for high frequency values and another capacitive arc, easier to extrapolate, for low frequency values. The presence of this two semicircles is related to the fact that different processes are taking place on the working electrode surface. As seen previously in the literature (15), this result suggests that the system can not be defined simply by a Randless circuit. The semicircle at high frequency values is associated with the formation of a layer on the working electrode surface. The semicircle at low frequencies is directly associated with the corrosion process. From the extrapolation of this last semicircle we can calculate the $R_{\mathrm{t}}$ parameter $\left(R_{\mathrm{t}}=\right.$ $3.7410^{5} \Omega \mathrm{cm}^{2}$ ). This value indicates that the formed layer is a low-protecting film.

Table 1 resumes the values of $R_{\mathrm{t}}$ and $R_{\mathrm{p}}$ for these different studied alloys. As mentioned above, taking the $R_{\mathrm{t}}$ values it is possible to obtain the $i_{\text {corr }}$ data by applying the Stern-Geary equation. From the represented data it is clear the best corrosion behaviour shown by the $\mathrm{Fe}_{62} \mathrm{Cr}_{10} \mathrm{Ni}_{8} \mathrm{Si}_{20}$ amorphous alloy.

In order to clarify the nature of the different corrosion resistance values observed in these alloys we performed XPS and AES measurements with the samples showing the two extreme corrosion behaviours. Therefore, $\mathrm{Fe}_{62} \mathrm{Cr}_{10} \mathrm{Ni}_{8} \mathrm{Si}_{20}$ and $\mathrm{Fe}_{62} \mathrm{Cr}_{10} \mathrm{Ni}_{8} \mathrm{P}_{20}$ alloy specimens, without any
TABLE I. $-R_{\mathrm{t}}$ and $R_{\mathrm{p}}$ values obtained after 15 days of immersion in $0.01 \mathrm{M} \mathrm{HCl}$ for the three studied alloys: $\mathrm{Fe}_{62} \mathrm{Cr}_{10} \mathrm{Ni}_{8} \mathrm{X}_{20}(\mathrm{X}=\mathrm{P}, \mathrm{B}, \mathrm{Si})$

TABLA I.- Valores de $\mathrm{R}_{\mathrm{t}}$ y $\mathrm{R}_{\mathrm{p}}$ depués de 15 días de immersión en $\mathrm{HCl} 0.01 \mathrm{M}$ para las tres aleaciones amorfas estudiadas: $\mathrm{Fe}_{62} \mathrm{Cr}_{10} \mathrm{Ni}_{8} \mathrm{X}_{20}(\mathrm{X}=\mathrm{P}, \mathrm{B}, \mathrm{Si})$

\begin{tabular}{|c|c|c|}
\hline Amorphous alloy & $R_{\mathrm{t}}, \Omega \mathrm{cm}^{2}$ & $R_{\mathrm{p}}, \Omega \mathrm{cm}^{2}$ \\
\hline $\mathrm{Fe}_{62} \mathrm{Cr}_{10} \mathrm{Ni}_{8} \mathrm{~B}_{20}$ & $44.210^{5}$ & $5.310^{5}$ \\
\hline $\mathrm{Fe}_{62} \mathrm{Cr}_{10} \mathrm{Ni}_{8} \mathrm{P}_{20}$ & $3.7410^{5}$ & $3.6410^{5}$ \\
\hline $\mathrm{Fe}_{62} \mathrm{Cr}_{10} \mathrm{Ni}_{8} \mathrm{Si}_{20}$ & $38.110^{7}$ & $1.1810^{7}$ \\
\hline
\end{tabular}

immersion in $\mathrm{HCl}$ solution, i.e., with passive layers generated via air contact, were analyzed. XPS spectra over a wide binding energy region showed peaks of carbon and oxygen in addition to those corresponding to the different alloy constituents. In order to obtain a material surface without contaminants 'both samples were sputtered with Ar ions during $10 \mathrm{~min}$ and after the carbon emission was negligible. After this, both samples showed different behaviours, as will be described below. All XPS spectra were analyzed by least squares fit procedures in order to obtain more information about the chemical state. The experimental data were described by Lorentz curves representing the different emission lines convoluted by a Gaussian function that takes into account the experimental resolution. In all spectra, the solid line through the data points represents the result of the least-squares fits, with the dashed subspectrum giving the signal corresponding to the oxidized component and the dotted curve showing the elemental component. The dashed-dotted curve represents the integral background.

Figure 3 shows $\mathrm{Cr} 2 \mathrm{p}_{3 / 2}$ core-level emission of $\mathrm{Fe}_{62} \mathrm{Cr}_{10} \mathrm{Ni}_{8} \mathrm{Si}_{20}$ after sputtering. As we mention above, the dashed subspectrum gives the signal corresponding to oxidized chromium $\mathrm{Cr}^{3+}$ at a binding energy (BE) of $576.7 \mathrm{eV}$. From figure 3 we can observe that there was no signal corresponding to elemental chromium, located at $574.5 \mathrm{eV} \mathrm{BE}$. Therefore, it is clear from this $\mathrm{Cr} 2 \mathrm{p}$ photoemission spectrum that the chemical state of chromium in the passive layer formed on the surface of the $\mathrm{Fe}_{62} \mathrm{Cr}_{10} \mathrm{Ni}_{8} \mathrm{Si}_{20}$ amorphous alloy is mainly a oxidized $\mathrm{Cr}^{3+}$ state and the content of elemental $\mathrm{Cr}$ is negligible.

Figure 4 represents the $\operatorname{Si} 2 p_{3 / 2}$ emission where the same procedure was applied. The Lorentzian located at $103.5 \mathrm{eV} \mathrm{BE}$, represented by the dashed curve, corresponds to $\mathrm{Si}$ in form of silica. From this figure we observe that there is no emission corresponding to elemental $\mathrm{Si}$ which should be 


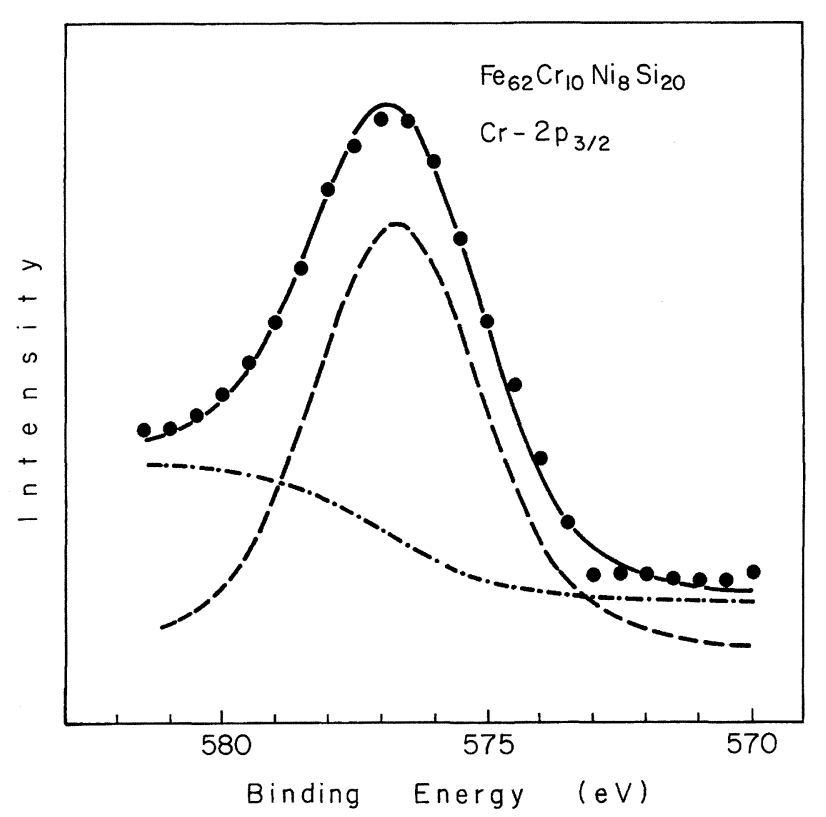

FIG. 3.- $\mathrm{Cr} 2 \mathrm{p}_{3 / 2}$ core-level photoemission spectrum of $\mathrm{Fe}_{62} \mathrm{Cr}_{10} \mathrm{Ni}_{8} \mathrm{Si}_{20}$. The dashed subspectrum represents the oxidized chromium emission.

FIG. 3.- Espectro de fotoemisión correspondiente a $\mathrm{Cr} 2 \mathrm{p}_{3 / 2}$ de la aleación $\mathrm{Fe}_{62} \mathrm{Cr}_{10} \mathrm{Ni}_{8} \mathrm{Si}_{20}$. El subespectro con líneas a trazos representa la emisión de Cr oxidado.

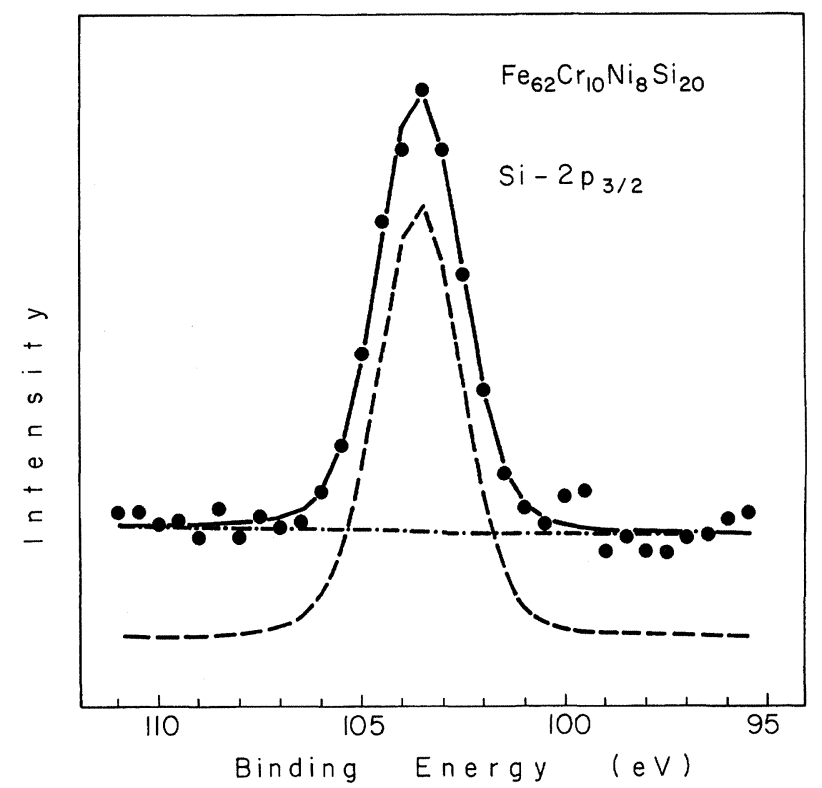

FIG. 4.- Si $2 p_{3 / 2}$ core-level photoemission spectrum of $\mathrm{Fe}_{62} \mathrm{Cr}_{10} \mathrm{Ni}_{8} \mathrm{Si}_{20}$. The dashed subspectrum represents silica emission.

FIG. 4.- Espectro de fotoemisión correspondiente a $\mathrm{Si} 2 \mathrm{p}_{3 / 2}$ de la aleación $\mathrm{Fe}_{62} \mathrm{Cr}_{10} \mathrm{Ni}_{8} \mathrm{Si} i_{20}$. El subespectro con líneas a trazos representa la emisión de sílice.

located at $99 \mathrm{eV} \mathrm{BE}$. This result indicates that $\mathrm{Si}$ chemical state in the passive layer is mainly in the form of silica.
It is important to mention that we did not observe any signal corresponding to $\mathrm{Fe}$ nor to $\mathrm{Ni} 2 \mathrm{p}$ emissions after $10 \mathrm{~min}$ of sputtering, this is related to the fact that the passive layer consisted only of $\mathrm{Cr}^{3+}$ oxide and oxihydroxide with some amounts of silica as it has been seen above.

After sputtering on $\mathrm{Fe}_{62} \mathrm{Cr}_{10} \mathrm{Ni}_{8} \mathrm{P}_{20}$ amorphous alloys, the spectrum recorded over a wide binding energy region showed, in addition to $\mathrm{Cr} 2 \mathrm{p}$ signal, $\mathrm{Ni} 2 \mathrm{p}$ and $\mathrm{Fe} 2 \mathrm{p}$ emissions, contrary to the previous case. $\mathrm{Cr} 2 \mathrm{p}_{3 / 2}$ core-level emissions were measured as it is shown in figure 5 . We analyzed this spectrum using two Lorentzians. The dashed subspectrum shows the signal corresponding to oxidized chromium $\mathrm{Cr}^{3+}$ located at $576.7 \mathrm{eV} \mathrm{BE}$ and the dotted subspectrum represents elemental chromium emission located at $574.4 \mathrm{eV} \mathrm{BE}$. This figure indicates that in the case of $\mathrm{Fe}_{62} \mathrm{Cr}_{10} \mathrm{Ni}_{8} \mathrm{P}_{20}$ the total $\mathrm{Cr} 2 \mathrm{p}$ emission is a mixture of elemental and oxidized chromium. The presence of elemental $\mathrm{Cr}$ in the passive layer is not expected and, conșequently, we assign the elemental component to emission from the amorphous alloy base material and not from the passive layer.

Figure 6 represents the $\mathrm{Fe} 2 \mathrm{p}_{3 / 2}$ emission for this sample. The dashed curve, located at $709.5 \mathrm{eV} \mathrm{BE}$, corresponds to oxidized $\mathrm{Fe}$ and the dotted curve at

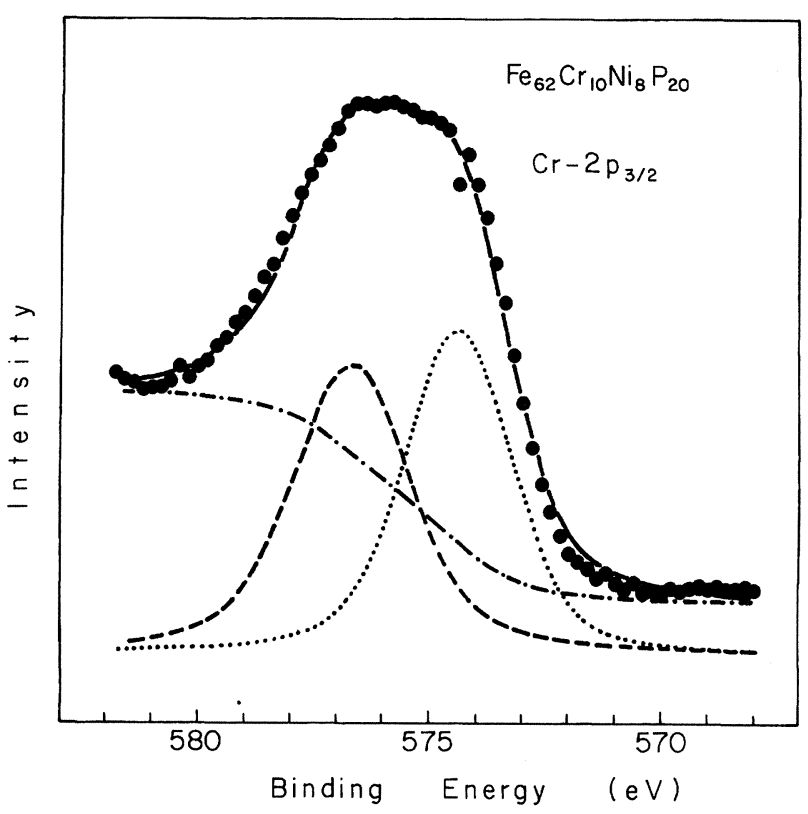

FIG. 5.- Cr $2 \mathrm{p}_{3 / 2}$ core-level photoemission spectrum of $\mathrm{Fe}_{62} \mathrm{Cr}_{10} \mathrm{Ni}_{8} \mathrm{P}_{20}$. The dashed subspectrum represents oxidized $\mathrm{Cr}$ and the dotted curve corresponds to elemental $\mathrm{Cr}$ emission.

FIG. 5.- Espectro de fotoemisión correspondiente a $\mathrm{Cr} 2 p_{3 / 2}$ de la aleación $\mathrm{Fe}_{62} \mathrm{Cr}_{10} \mathrm{Ni}_{8} \mathrm{P}_{20}$. El subespectro con líneas a trazos representa $\mathrm{Cr}$ oxidado y la curva a puntos corresponde a la emisión de Cr elemental. 


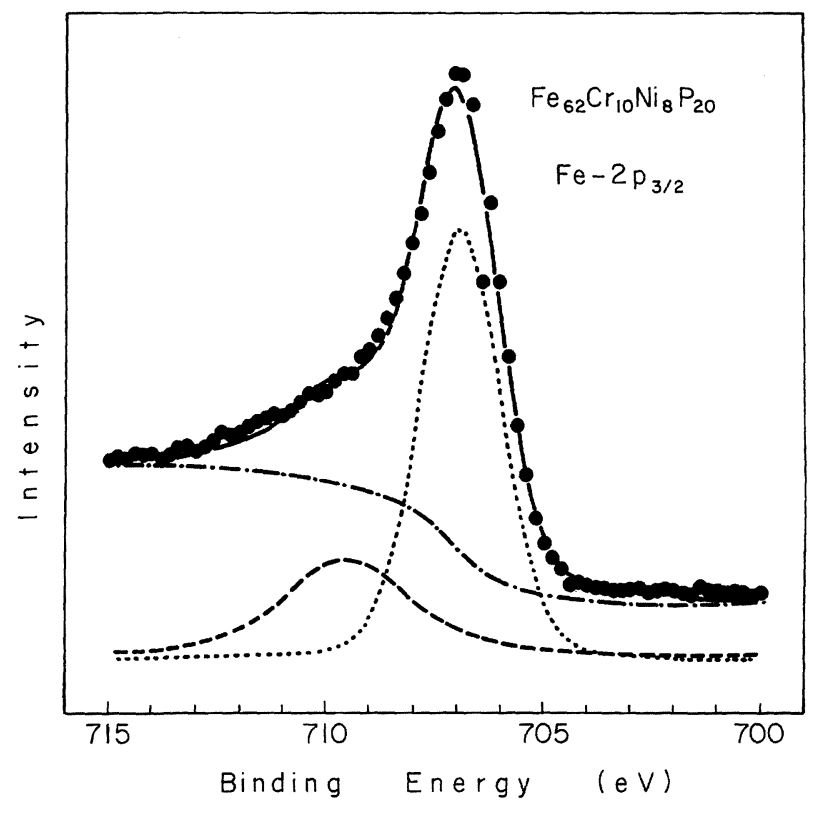

FIG. 6.- $\mathrm{Fe} 2 \mathrm{p}_{3 / 2}$ core-level photoemission spectrum of $\mathrm{Fe}_{62} \mathrm{Cr}_{10} \mathrm{Ni}_{8} \mathrm{P}_{20}$. The dashed subspectrum represents oxidized $\mathrm{Fe}$ and the dotted curve corresponds to elemental Fe emission.

FIG. 6.- Espectro de fotoemisión correspondiente a $\mathrm{Fe} 2 p_{3 / 2}$ de la aleación $\mathrm{Fe}_{62} \mathrm{Cr}_{10} \mathrm{Ni}_{8} \mathrm{P}_{20}$. El subespectro con líneas a trazos representa $\mathrm{Fe}$ oxidado y la curva a puntos corresponde a la emisión de Fe elemental.

$707 \mathrm{eV}$ BE represents the elemental Fe state. This figure suggests the presence of oxidized $\mathrm{Fe}$ in the passive film. As in the $\mathrm{Cr} 2 \mathrm{p}$ spectrum, the elemental $\mathrm{Fe}$ emission is coming from the amorphous substrate.

Figure 7 shows the Ni $2 p_{3 / 2}$ emission that was described by two Lorentzians. The dotted curve located at $852.7 \mathrm{eV} \mathrm{BE}$ represents the elemental $\mathrm{Ni}$ state and the dashed curve at $854 \mathrm{eV} \mathrm{BE}$ represents the oxidized state. From this figure we can see the presence of oxidized $\mathrm{Ni}$ in the passive layer, as well as an elemental $\mathrm{Ni}$ component coming from the alloy substrate. We measured the $P 2 p$ photoemission signal, which showed an emission line at approximately $130 \mathrm{eV}$, indicating that the $\mathrm{P}$ chemical state corresponds to elemental phosphorous without oxidized contribution. Since we observe that the passive layer on $\mathrm{Fe}_{62} \mathrm{Cr}_{10} \mathrm{Ni}_{8} \mathrm{P}_{20}$ is formed not only by oxidized $\mathrm{Cr}$ but also by oxidized $\mathrm{Fe}$ and $\mathrm{Ni}$, this layer is less uniform and less resistant than that formed on $\mathrm{Fe}_{62} \mathrm{Cr}_{10} \mathrm{Ni}_{8} \mathrm{Si}_{20}$. This explains why with the same sputtering time it vanishes faster and, that after 10 min sputtering we collected elemental $\mathrm{Fe}, \mathrm{Ni}$ and $\mathrm{P}$ emissions from the substrate.

The XPS results indicate that the passive layer formed on the surface of $\mathrm{Fe}_{62} \mathrm{Cr}_{10} \mathrm{Ni}_{8} \mathrm{Si}_{20}$ contains

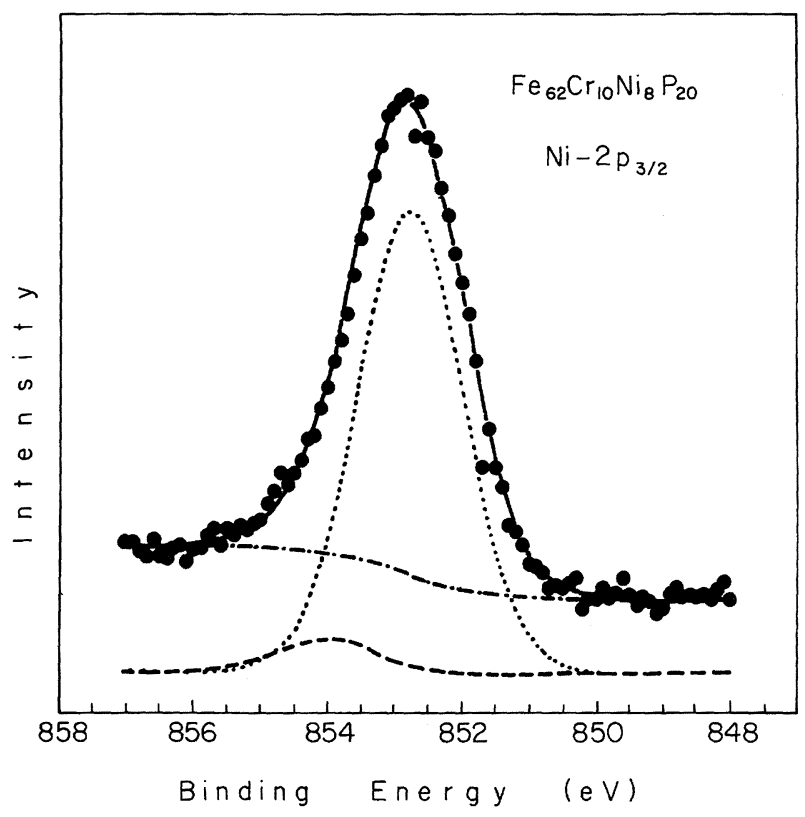

FIG. 7.- Ni 2 $\mathrm{p}_{3 / 2}$ core-level photoemission spetrum of $\mathrm{Fe}_{62} \mathrm{Cr}_{10} \mathrm{Ni}_{8} \mathrm{P}_{20}$. The dashed subspectrum represents oxidized $\mathrm{Ni}$ and the dotted curve corresponds to elemental $\mathrm{Ni}$ emission.

FIG. 7.-Espectro de fotoemisión correspondiente a $\mathrm{Ni} 2 p_{3 / 2}$ de la aleación $\mathrm{Fe}_{62} \mathrm{Cr}_{10} \mathrm{Ni}_{8} \mathrm{P}_{20}$. El subespectro con líneas a trazos representa $\mathrm{Ni}$ oxidado y la curva a puntos corresponde a la emisión de Ni elemental.

oxidized $\mathrm{Cr}$ and silica without any $\mathrm{Ni}$ and $\mathrm{Fe}$ signals, contrary to the case of the $\mathrm{Fe}_{62} \mathrm{Cr}_{10} \mathrm{Ni}_{8} \mathrm{P}_{20}$ surface, which also showed the presence of $\mathrm{Fe}$ and $\mathrm{Ni}$ oxides. The results are in agreement with the results of the electrochemical measurements since a higher content of $\mathrm{Cr}^{3+}$ in the passive layer indicates a better corrosion behaviour (10). For the $\mathrm{P}$ containing alloy, the presence of several oxides decreases the corrosion resistance of the passive layer which is less uniform and less resistant than the layers formed only by $\mathrm{Cr}$ oxide.

The AES results showed that for the $\mathrm{Fe}_{62} \mathrm{Cr}_{10} \mathrm{Ni}_{8} \mathrm{Si}_{20}$ amorphous alloy the amount of $\mathrm{Cr}$ and $\mathrm{O}$ remained almost constant when we performed 2 min sputtering cycles up to a total sputtering time of $10 \mathrm{~min}$, with no traces of $\mathrm{Fe}$ and Ni. However, for $\mathrm{Fe}_{62} \mathrm{Cr}_{10} \mathrm{Ni}_{8} \mathrm{P}_{20}$ alloy, applying the same sputtering cycles up to a total sputtering time of $10 \mathrm{~min}, \mathrm{Cr}, \mathrm{O}, \mathrm{Fe}$ and $\mathrm{Ni}$ emissions were observed. The $\mathrm{Fe}_{62} \mathrm{Cr}_{10} \mathrm{Ni}_{8} \mathrm{Si}_{20}$ AES results agree with the XPS measurements suggesting that at different depths the passive layer formed on this amorphous alloy is constituted mainly by oxidized Cr. However, for the $\mathrm{Fe}_{62} \mathrm{Cr}_{10} \mathrm{Ni}_{8} \mathrm{P}_{20}$ case, the results show that the passive layer is formed by oxidized $\mathrm{Cr}, \mathrm{Fe}$ and $\mathrm{Ni}$. 


\section{CONCLUSIONS}

We have shown by applying electrochemical technics to $\mathrm{Fe}_{62} \mathrm{Cr}_{10} \mathrm{Ni}_{8} \mathrm{X}_{20}(\mathrm{X}=\mathrm{P}, \mathrm{B}, \mathrm{Si})$ amorphous alloys that the best corrosion behaviour is given by the $\mathrm{Si}$-containing alloy. The corrosion resistance is determined mainly by the presence of a protective film formed on the surface of the alloy. The composition of this film plays a fundamental role in this corrosion behaviour, as we showed by the XPS and AES measurements. For the case of $\mathrm{Fe}_{62} \mathrm{Cr}_{10} \mathrm{Ni}_{8} \mathrm{Si}_{20}$ the study revealed a passive layer formed by oxidized chromium with some amounts of silica and with no contribution of other metal oxides. On the other hand, $\mathrm{Fe}_{62} \mathrm{Cr}_{10} \mathrm{Ni}_{8} \mathrm{P}_{20}$ showed a passive layer formed by a mixture of metal oxides. These results are in agreement with the corrosion studies because a passive layer formed mainly by oxidized chromium enhances greatly the corrosion resistance.

\section{Acknowledgements}

The authors wish to thank the Comisión Interministerial de Ciencia y Tecnología (CICYT) for the project MAT92-0395.

\section{REFERENCES}

(1) Diegle, R. B. Corrosion, 35, 1979: 250.
(2) DiEgle, R. B. Corrosion, 36, 1980: 362.

(3) Diegle, R. B. and Lineman, D. M. J. Electrochem. Soc., 131, 1984: 106.

(4) Hashimoto, K. and Masumoto, T. Mater. Sci. Eng., 23, 1976: 285.

(5) Crousier, J., Antonione, C., Massiani, Y. and Crousier, J.P. Mater. Chem., 7, 1982: 587.

(6) Massiani, Y., Crousier, J., PicQ, G. and Vennereau, P. Surface Sci., 162, 1985: 801.

(7) NaKa, M., Hashimoto, K. and Masumoto, T. CorrosionNACE, 32, 1976: 146.

(8) NaKa, M., Hashimoto, K. and Masumoto, T. J. NonCrystall. Solids, 28, 1978: 403.

(9) Yu, V., Vasil'ev, , Isaev, N.I., Shumilov, V.N., KlochKo, A.N., Zakharov, A.I. and Revyakin, A.V. Prot. Metals., 19, 1983: 203.

(10) Hashimoto, K., NaKa, M., Noguchi, J., Asami K. and Masumoto T. Passivity in Metals. Ed. Frankental Kruger. The Electrochem. Soc. Princenton, 1978: 161.

(11), Parkins, R.N. Stress Corrosion Research. Ed. H. Arup and R. N. Parkins. Sijthoff \& Noordoff, Alphen aan den Rijn (The Netherlands), 1979: 29.

(12) Hashimoto, K. Suplement Sci. Rep. Ritu, 1980: 4.201.

(13) Masumoto, T. and Hashimoto, K. Ann. Rev. Mater. Sci, 1978: 215.

(14) Virtanen, S., Moser, E.M. and Böhni, H. Corros. Sci., 36, 1994: 373.

(15) Thompson, I. and Campbell, D. Corros. Sci., 36, 1994: 187. 